\title{
The Main Aspects of the Formation of Digital Competence of Future Civil and Municipal Employees
}

\author{
I.V. Gaidamashko, Y.I. Zhemerikina, O.S. Zhigalov, I.P. Provorova, O.V. Titkova
}

\begin{abstract}
This study presents experimental work on the study of psychological and pedagogical conditions for the formation of digital competence of future civil and municipal employees. This research is carried out within four years on the basis of the Federal state budgetary educational institution of higher education «MIREA - Russian Technological University»

Index Terms: digital competence, information technology, future managers, civil servants, a set of conditions for the formation of competence
\end{abstract}

\section{INTRODUCTION}

The modern state needs highly qualified personnel who are able to make strategic decisions, be able to think creatively and be competitive. Today, the most important task of educational institutions is to produce highly qualified specialists who, in addition to these qualities, have the ability to continuously improve and update knowledge. Education forms a wide variety of competencies. A highly qualified specialist in our state must have formed a digital competence, and this is especially true for employees of public authorities. This can be achieved only as a result of competent construction of the educational process and taking into account the psychological and pedagogical conditions of the formation of digital competence. Competent civil servants are the key to a strong and stable state [1].

Applied problem. The modern state has many requirements for the quality and training of specialists future civil and municipal employees. Digital society is characterized by comprehensive Informatization, where an important role is played by the management aspect.

Modern Russia needs professional staff capable of developing throughout its working life, to solve tasks, to think creatively and outside the box [2].

Revised Manuscript Received on July 09, 2019.

I.V. Gaidamashko, Y.I. Zhemerikina, O.S. Zhigalov, I.P. Provorova, O.V. Titkova, MIREA - Russian Technological University, Moscow, Russia

\section{RESEARCH METHOD}

Theoretical: analysis of literature on the studied problem; logical and pedagogical analysis of educational standards; methods of statistical analysis of experimental data; theoretical generalization of the results of experimental work. Empirical: pedagogical observation; surveys; testing; pedagogical experiment; product analysis activities of students

\section{RESULTSANDANALYSIS}

The decree of the President of the Russian Federation of may 7, 2012 №601 "On the main directions of improving the system of public administration" provides that the continuous training of civil servants contributes to their better understanding of the relationship of their management decisions and the resulting effect. A citizen admitted to the public service must develop the skills and abilities to govern on behalf of the state in accordance with its laws and regulations[3].

E. Toffler in his book "Metamorphoses of power" notes that the use of information technologies contributes not only to changes in the economy, but also to changes in the structure of employment, which affects the social, psychological components of a person [4].

The digital economy is increasingly developing. The Russian Federation has created a program for the development of the digital economy, which lists the directions of development of the digital economy, the management of this economy, the key objectives of the program and ways to achieve them. This program was approved by the Russian Government on July 27, 2017.

In this regard, the state increases the role of research and improvement of the education system of future managers. A strong country needs professional staff who are able not only to see the problem, but also to solve it successfully. Today, the most important task is to produce highly qualified specialists with a qualitatively new level of knowledge and the ability to continuously improve and update them. In the era of digitalization education is in constant motion -changing standards, curricula, etc., ie. there are changes both in the content of education and in the organizational.

Novelty. In our study, digital competence is 
considered as an acquired quality of a person during the training at the University, allowing him to effectively carry out various manipulations with information (search, research), the creation of psychological and pedagogical conditions for the development of digital competence. [5]

The analysis of scientific literature shows that today it is possible to carry out the comprehension of this problem.

The issues related to digital competence of students of technical specialties, as reflected in the works of A. A. Golubin, L. V. Dobrova, I. N. Zavialov, L. B., Sienkiewicz, M. M. Pshukova etc.

Some researchers (K. A. Abulkhanova-Slavskaya, L. A. Petrovskaya, M. A. Kholodnaya, etc.) address the problem of competence formation in a broad sense.Issues of professional competence engaged in A. A. Derkach, A. K. Markova, E. A. Klimov, I. A. Slastenin, etc. Investigated a total vorosilova competency V. L. Akulenko, A. V., Gotherburg, T. G. Golovko, M. G. Dzagoeva, O. B. Zaitseva [6] et al. Touches upon the issue of studying the relationship between the intensity of innovation activity and the level of innovation activity with the pace of development of high technologies, as a result of which confirmed such personnel problems as the lack of young specialists in scientific and engineering specialties, relatively low efficiency of their intellectual activity, low efficiency of innovation, hindering the improvement of the technological level of the economy [7].

The analysis of various sources showed that the problem of formation of digital competence in future specialists is considered by many researchers, despite the large number of works performed and their importance, it should be noted that the study of the conditions and the process of formation of digital competence in future managers remains open to theoretical understanding and experimental study.

A number of unresolved problems include a number of contradictions between:

- developing a single information space and the lack of an experimental base for the study of conditions and the formation of digital competence in future managers;

- social demand for effective managers with a sufficient level of development of digital competence and insufficiency of theoretical and practical development of conditions, methods of formation of this competence.

Object of research: the process of formation of digital competence of future managers.

Subject: complex psychological and pedagogical conditions that contribute to the formation of digital competence in future managers.

Hypothesis of the study: we proceeded from the assumption that the formation of digital competence can be provided by creating a set of certain psychological and pedagogical conditions and the introduction of this complex into the practice of the educational institution:

- introduction of special subjects for the study,

- organization of information training activities,

- involvement of specialists of information companies in practical training, internships of students.

The complex of psychological and pedagogical conditions of effective formation of digital competence of future managers in the process of training at the University is theoretically substantiated and experimentally tested.

\section{CONCLUSION}

The experiment was attended by 100 students of the Federal state budgetary educational institution of higher education "MIREA - Russian Technological University" of the Institute of innovative technologies and public administration in the areas of training 38.03.04 State and municipal administration.

Logic and stages of research.

At the first stage of the study, a hypothesis was formed, documentation was prepared and students were enrolled in the direction of training 38.03.04 State and municipal administration. Beginning of training in this specialty at the Institute of ITSU in MIREA.

At the second stage, the development of disciplines and additional literature, the involvement of specialists from the it sphere, civil servants to create psychological and pedagogical conditions and the study of their impact on the process of formation of digital competence. Training of students and the introduction of disciplines that contribute to the development of both digital competence and comprehensive development of the individual (development of the information society, information security policy, psychology of civil servants, etc.). At this stage, practices play an important role. Future managers went to practice in centres, the Ministry of communications, notaries, municipal administrations, Federal tax service, etc. In seminars in many disciplines were invited experts from leading companies and enterprises.

The third stage is processing the results.

As a result of the analysis of data it is established that the digital competence of future civil servants develops not only in training, but also with the development of spiritual and moral principles, a sense of responsibility, creativity. The competence-based form of training of a civil servant has a multi-level system and some competencies derive from others. The formation of competencies is not only the knowledge, skills and abilities that should have a future civil servant, but also the development of unity of theoretical and practical readiness to carry out professional activities. Thus, it is reasonable to create a competent form, where theoretical training is aimed at generalization and structuring of knowledge, and practices in public authorities and seminars with representatives of large it companies provide generality and functionality of knowledge, actions and provide an opportunity at the moment to try to trace the implementation of laws in the state in practice. Practical training of students and real interaction with civil servants help to form psychological and pedagogical conditions for the formation of digital competence of future civil and municipal employees. In the process of implementing the competent form of training of a civil servant, the state receives a specialist who meets all the requirements, and the student successfully enters 
the profession and works in the chosen specialty. The potential of this form of training is evidenced by the empirical data of the study: reviews of the learning process of the students themselves, reviews of the quality of training of young personnel of potential employers, the performance of students.

\section{REFERENCES}

[1] Zhemerikina Y.I., Provorova I.P. Positive and negative aspects of information competence // Human capital. 2016. № 6 (90). P. 30-31

[2] Malysheva V.V. Formation of professional competence of public servants in the financial sector in the process of continuing education Text.: author. dis. ...cand. PhD. Volgograd. 2017. 25 p.

[3] Decree of the President of the Russian Federation of may 7, 2012 №601 "On the main directions of improving the system of public administration."

[4] Toffler, Alvin. Powershift: Knowledge, Wealth and Violence at the Edge of the 21 st Century, 1990.

[5] Zhemerikina Y.I., Provorova I.P., Pugacheva E.V. Psychological aspects of the formation of media literacy among students of technical University// "Modern science: theoretical and practical view: materials of the International scientific and practical conference" (March 28, 2015, Ufa). Ufa: RIO ICII OMEGA SAINZ, 2015. - P. 202-205

[6] Zaytseva O.B. Formation of information competence of future teachers by means of innovative technologies Text.: autoref. dis. ...cand. PhD. Bryansk. 2002. 19 p.

[7] Rogova V.A. Problem of staffing for development of high technologies in russia in the mirror of the global innovation index. // Russian technological journal. 2018. V 6 № 4, p. 105-116.

URLhttps://rtj.mirea.ru/upload/medialibrary/f3d/RTZH_4_2018_105_1

16.pdf 